\title{
İstanbul Şehir Üniversitesinde Arapça öğretim tecrübesi
}

Ali TÜLÜ2

\section{Muhammed Raşid DERŞEVİ3}

\begin{abstract}
APA: Tülü, A. (2019). İstanbul Şehir Üniversitesinde Arapça öğretim tecrübesi. RumeliDE Dil ve
\end{abstract} Edebiyat Araştırmaları Dergisi, (16), 234-248. DOI: 10.29000/rumelide.618684

\section{$\ddot{O} \mathbf{z}$}

İnsanlar tarihin akışı içerisinde farklı zorunluluklar ve hedefler neticesinde anadillerinin dışında başka dilleri öğrenme ihtiyacı hissetmişlerdir. Bu ihtiyacı hisseden bir kimseye konuştuğu anadilinin dışında bir dili (yabancı dil) öğretmek iyi bir planlama ve bir süreç ister. Bu planlamada muhatap kitlenin bu dili öğrenmedeki amaç ve ihtiyaçları göz önüne alınarak bir müfredat ve program hazırlanmalı ve yine bu muhatap kitleye en uygun yöntem ve materyaller kullanılarak öğretim süreci sürdürülmelidir. Yabancı dil öğretimi ile ilgili tarihi süreç içerisinde birçok yöntem, esas ve materyal denenmiş, pek çok tecrübe elde edilmiştir. Kullanılan bu yöntem, esas ve materyaller geliştirilerek dönemin şartlarına ve muhatap kitleye uygun olarak müfredat ve programlar hazırlanmıştır. Biz bu makalede İstanbul Şehir Üniversite'sinde yabancı dil olarak Arapçanın öğretiminde yararlandığımız yöntem, esas ve materyalleri ve bunlar ışı̆̆ında geliştirdiğimiz müfredat ve program tecrübesini paylaştık.

Anahtar kelimeler: Arapça öğretimi, Arapça, yabancı dil, Şehir Üniversitesi.

\section{Arabic teaching experience at İstanbul Şehir University}

\begin{abstract}
People felt need to learn languages other than their mother tongue as a result of different necessities and goals throughout history. Teaching a language (foreign language) to a person who feels this need apart from native language requires well planning and process. In this planning, curriculum and program should be prepared considering the aims and needs of the audience and the teaching process should be continued by using the most appropriate methods and materials for the audience. During the historical process of teaching foreign languages, many methods, principles and materials have been tried and many experiences have been gained. These methods, principles and materials have been developed and curriculum and programs have been prepared in accordance with the conditions of the period and the respondent audience. In this article, we shared the methods, principals and
\end{abstract}

Bu makalemiz, 20-22 Eylül 2018 tarihinde İstanbul Sabahattin Zaim Üniversitesi ile International Islamic Schools Alliance (Endonezya)'nin organize ettiği "The Challenges of Arabic Teaching and Learning for Non Native Speakers - The Experiences in Turkey, Indonesia and Other Countries/Anadili Arapça olmayanlar için Arapça Öğretimi ve Öğreniminin Zorlukları - Türkiye, Endonezya ve Diğer Ülkelerde Yaşanan Deneyimler-” konulu uluslararası konferansta "Arapça Öğretiminde Şehir Üniversitesi Tecrübesi” başlıklı tebliğimizin gözden geçirilmiş ve mezkur üniversitede Arapça öğretim programı oluşturulurken bu programın temelini oluşturan "dil öğretim yöntem ve esasları”nın anlatıldı̆̆ı bir bölüm eklenmiş halidir. Bu yayın için kurumdan 09.08.2019 tarihli 55753029/234 sayılı izin belgesi mevcuttur.

2 Dr. Öğr. Üyesi, İstanbul Şehir Üniversitesi, İslami İlimler Fakültesi, Temel İslam İlimleri Bölümü (İstanbul, Türkiye), alitulu@sehir.edu.tr, ORCID ID: 0000-0002-3245-2744 [Makale kayit tarihi: 01.08.2019-kabul tarihi: 20.09.2019; DOI: 10.29000/rumelide.618684]

3 Öğr. Gör., İstanbul Şehir Üniversitesi İslami İlimler Fakültesi, Arapça Hazırlık Okulu Koordinatörü (İstanbul, Türkiye), mohammaddeirchawi@sehir.edu.tr, ORCID ID: 0000-0003-3023-9760. 
materials that we use in teaching Arabic as a foreign language in Istanbul Sehir University and discussed the curriculum and experience we developed in the light of these methods.

Keywords: Arabic teaching, Arabic, foreign language, Sehir University.

\section{Giriş}

Dil, insanlar arasındaki en etkili iletişim aracıdır. Yeryüzünde yaşayan her bir insan topluluğu ister medeniyetten büyük bir pay ister küçük bir pay almış olsun tarih boyunca mutlaka kendi aralarında iletişim kurdukları, fikir ve duygularını birbirlerine ifade ettikleri bir dile sahiptirler (Hâtır, Şehhate ve Azazi, 1990, s.333,336; Demirel, 2003, s.2). Ayrica bugünün dünyasında da insan birden fazla dil öğrenmeye ihtiyaç duymaktadır. Bu ihtiyacı doğuran temel sebep ise devletlerarası ilişkilerin sonucu olarak ortaya çıkan toplumsal, siyasî ve iktisadî maslahatlardır (Hâtır ve diğerleri, 1990, s. 333, 336; Demirel, 2003, s.2).

Her medeniyetin üzerine inşa edildiği bir dil mevcuttur. Farklı dilleri konuşsalar da farklı milletlere mensup olsalar da aynı medeniyetin mensubu olanlara referans olma özelliği taşıyan klasik eserler medeniyetin ortak dili ile yazılmaktadır (Hâtır ve diğerleri, 1990, ss. 48-49, 337-338; Özdemir, 2004, ss.98-99). İslam Dini ve medeniyetinin iki temel kaynağı olan Kur'an-ı Kerim'in ve Hadis-i şeriflerin dilinin Arapça olmasının da etkisiyle, bu dil, müslüman milletlerin ortak kültür, medeniyet ve bilim dili olmuştur. Bu özelliği Arapça'yı Müslümanların nazarında önemli kılmış ve onu zamanlar üstü özel bir konuma yerleştirmiştir (el-Huli, 1982, ss.19-20; Özdemir, 2004, ss.98-99; Soyupek, 2004, s.98). Öte yandan Arapçanın uluslararası alanda yaygın bir dil olması ve ülkemiz ile Ortadoğu ülkeleri arasındaki ilişkilerin son zamanlarda önem kazanması (el-Huli, 1982, ss.19-20; Hâtır ve diğerleri, 1990, ss. 48-49; Doğan, 2006, s.70) uzun ylllar ilahiyat fakültelerinde özellikle İslamî ilimlerin öğretim dili olarak öğretilen Arapçanın bir iletişim dili olarak da öğrenilmesinin önemini arttırdı.

İşte bu farklı amaç ve ihtiyaçlara binaen bir kimseye anadili olmayan/kendisiyle konuşmadığı bir dili öğretmek dünyanın en meşakkatli işlerinden biridir. Kişinin, bir dili o dille konuşmayan birine öğretebilmesi için bu konuda onu yeterli kılabilecek özelliklere sahip olması gerekmektedir. Ayrıca bu kişinin kullandığı yöntem yeniliklere açık ve uygulanabilir olmalı, katı olmamalı ki farklı grup ve milletlere mensup olanlara bu yolla dil öğretilebilsin (Şakir, ss. 373-375). Biz öğretim yöntemimizi ve müfredatımızı oluştururken genel kabul gören bazı dil öğretim yöntemlerinden ve esaslarından istifade ettik. Makalemizin birinci bölümünde istifade ettiğimiz yöntem ve esasların temel özelliklerini, güçlü ve zayıf yönlerini özetledik.

\section{Bölüm}

\section{A. Programın hazırlanmasında istifade edilen dil öğretim yöntemleri:}

1. Dilbilgisi-çeviri yöntemi (Grammar translation method): Bu yöntem, dilin yapı ve anlam kalıplarını çok iyi öğretip hata yapmayı önleme düşüncesiyle disipline edilmiş bir sistem olarak bilinir (Doğan, 2012, s.68). Yabancı dil öğretiminde ilk kullanılan ve tarihî süreç içinde kullanımı devam eden bugün hala etkinliğini (Bostancı, 2003, s.54) sürdüren bir yöntemdir. Asırlardır uygulanan bu yöntem "klasik yöntem" diye de isimlendirilmektedir (el-Huli, 1982, s.20; Deliçay, 2001, s.91-92; Doğan, 2006, s.70). Ders materyallerini sadece kitapların oluşturduğu bu yöntemde amaç edebî metinlerin okunup anlaşılması ve öğrencinin klasik eserlerin güçlü mantık örgüsünü anlaması ve bu zihinsel disiplini kazanmasıdır. Özellikle okuma anlama becerilerine yönelik olan bu yöntem de konuşma dilinden daha 
çok yazılı dil kuralları önem kazanır. Bu yöntemin edebî müktesebat kazandırmakla birlikte zihinsel disiplin ve entelektüel gelişme sağlama gibi hedefleri de vardır (el-Huli, 1982, s.21; Hâtır ve diğerleri, 1990, ss.353-354; Doğan, 2006, ss.70-72, 77, 80, 84). Hedef dildeki kelimeleri anadile çevirerek güçlü kelime bilgisi kazandırması, hedef dilin anlamsal yapısını kavratması, dilin söz dizimi kurallarını öğretmesi ve tümevarım yöntemiyle özellikle doğru çeviri becerisi kazandırmakta etkili bir yöntemdir (el-Huli, 1982, s.21; Hâtır ve diğerleri, 1990, ss.353-354; Demirel, 2003, ss.30-31). Özellikle akademik çalışma yapanların ihtiyaç duydukları okuma becerilerini (Soyupek, 2004, s.11-12) en etkili biçimde geliştiren bu yöntemdir.

Yukarıda anlatılan özellikleri göz önüne alındığında İslamî metinlerin okunup anlaşılabilmesi için en önemli yöntem Dil bilgisi-Çeviri yöntemidir (Müezzin, 2016, ss.106-107). İslam coğrafyasında yüzyllarca etkili olmuş eğitim-öğretim kurumları olan medreselerde de İslami ilimlerin öğretimi bu yöntemle yapılmaktaydı (Deliçay, 2001, s.92).

$\mathrm{Bu}$ yöntemde İslamî metinlerin okunup anlaşılabilmesinin yanı sıra Arapçanın gramerini öğrenmek/öğretmek neredeyse gayeye dönüşür öyle ki çok ayrıntılı bilgiler ve zayıf kullanımlar da öğretilerek hedef dili öğrenmek gramer kurallarını öğrenmekle neredeyse eşdeğer kılınır. Bunun sonucunda gramerin öğrenilmesi gereken adeta kendine özgü bir dili oluşur. Eşdeğer kılma ve adeta gramerin ayrı bir dilinin oluşması bu yöntemin aldığı en önemli eleştiridir (Başkan, 1969, ss.34-35; Demirel, 1990, s.33; Doğan, 2012, ss.68-71,84-85). Yukarıda da izah edildiği üzere okuma-anlama ve tercüme öğrenimini temel öğretim araçları olarak kabul eden bu yöntemde konuşma, dinleme ve yazma becerileri neredeyse yok hükmündedir.

Özellikle dilsel iletişimin ön plana çıkması ve bu yönde ihtiyaçların artması dinleme ve konuşma becerilerine verilen önemi arttırdı. Buna bağlı olarak dinleme ve konuşma becerisini kazandıran materyaller ile bu becerileri geliştirmeye uygun yeni öğretim yöntemleri ortaya çıktı (Doğan, 2012, ss.67, 77, 84-85). Bugün uygulanan yabancı dil öğretim yöntemleri de değişen şartların etkisiyle dil bilgisiçeviri yöntemi ile bağlantılı olarak ortaya çıkmıştır (Demirel, 1990, s.32-33; Doğan, 2012, ss.66-67,70).

\section{Düzvarım yöntemi/doğal yöntem (Direct method):}

"Bir öğrenci topluluğuna, ilk dersten itibaren öğretmen tarafindan yalnızca hedef dil kullanılarak, sürekli konuşma yoluyla iletişim kurmak ve bu etkileşimi birbiriyle bir metin oluştururcasına bağlantılı, ama dilbilgisi açıklaması yapılmaksızın anlaşılabilecek ölçüde yalın bir tümce dizisiyle gerçekleştirmektir" (Demircan, 2013, ss.163-164).

Tarihin her döneminde çocuklarına iyi bir dil eğitimi verdirmek isteyen aileler anadili, hedef dil olan mürebbiyeler eliyle bu eğitimi verdirmişlerdir (Hâtır ve diğerleri, 1990, ss.354; Doğan, 2012, ss.88)4. Bu yöntemde, öğrenci, bir çocuğun kendi anadilini öğrendiği gibi -fitri bir şekilde- ve sürekli aktif tekrarlarla öğrenmeye çalışır, öğrencinin anadilini kullanmasına asla izin verilmez. Öğretmen rol modeldir ve dil öğretimi özellikle öğretmenin üzerindedir (el-Huli, 1982, s.22; Hâtır ve diğerleri, 1990, ss.354; Demirel, 2003, ss.32-34; Müezzin, 2016, ss.102). Bu yöntem sözlü iletişim becerisi ile temel yazılı iletişim becerisini öğrenciye büyük ölçüde kazandırır. Hedef dilinin yaşanarak öğretildiği bu yöntemde öğretimin ileri seviyelerinde de doğru telaffuz ve dilbilgisi kurallarına yoğunlaşılır. Özellikle görsel materyaller çok kullanılır (Demirel, 1990, s.34-39; Doğan, 2012, s.106).

$4 \quad$ Bu öğretimin doğal yönteme değil özel öğretim’e girdiğine dair bkz. Ömer Demircan, Yabancıdil Öğretim Yöntemleri, 5. bs., İstanbul, Der Yayınları, 2013, s.164 
Bu yönteme yöneltilen eleştirilerin başında öğrencilerin dilbilgisi kurallarında oldukça zayıf kalmaları, ve metin çözümlemede başarılı olamamaları gelmektedir. Öğretim, öğretmen temelli devam ettiği için öğretmenin yetersiz olduğu durumlar bu yöntemin tamamen işlevsiz kalmasına sebep olmaktadır. Ayrıca anadili kullanmamak bazen basitçe kısa sürede anlatılabilecek şeylerin çok zaman ve enerji sarf ederek anlatılmasına sebep olmaktadır. Bu yöntemin eleştirilen bir başka yönü ise, her yaş grubunun aynı eğitime tabi tutulduğundan yetişkin öğrenci gruplarında çok başarılı olamamasıdır. (el-Huli, 1982, s.22-23; Demirel, 2003, ss.33-34; Doğan, 2012, ss.106-107)

3. Kulak dil alışkanlı̆̆ı yöntemi (Audio-lingual method): "İşitsel-dilsel yöntem”, "Askerî yöntem” olarak da bilinir. Bu yöntemde dil bir alışkanlıklar bütünü olarak tanımlanmıştır. Bu yüzden dil öğretiminde alışkanlık oluşturan etkinliklerin özellikle diyalogların kullanımına ağırlık vermiştir. Dilin "taklit-ezber" tekniğiyle öğretildiği (Enginarlar, 1983, ss.49-50; el-Huli, 1982, s.23; Demirel, 1990, ss.37,39,41) bu yöntemde özellikle ilk dönemlerde basit aktiviteleri ifade eden kelime ve cümleler çok sık tekrarlanarak öğrenciye hedef dil ile hareket edebildiği anlayışı verilmeye çalışılır. Bu yönteme göre dil öğrenimi kelime ve gramer öğrenimi değil konuşma becerisi olduğundan okuma ve yazma becerisi sonraki dönemlere bırakılır ve dilbilgisi kuralları, geçen diyaloglar içerisinde öğretilir. (Enginarlar, 1983, ss.49-50; Hâtır ve diğerleri, 1990, ss.354; Demircan, 2013, ss.212-213) Ayrıca bu yönteme göre dil, anadilin "konuşma dili”dir. Bu yüzden özellikle ilk dönemlerde kurala uygunluğu çok önemsemez. Bu yöntemde temel hedef öğrencinin hedef dil ile iletişim kurması olduğundan dilbilgisi kuralları temele koyulmaz, ezberlenilmesi için kelime listeleri verilmez. (Demirel, 1990, ss.34-36; Doğan, 2012, ss.115, 199-121)

$\mathrm{Bu}$ yöntem özellikle dinleme ve konuşma becerisini güçlü kllarken diğer becerilerde ve dilbilgisi kurallarında oldukça eksik kalmakta ve öğrenci sürekli tekrarlanan diyaloglardan sıkılmaktadır. (Demirel, 1990, ss.41; Doğan, 2012, ss. 199-121; Demircan, 2013, ss.216-218)

4. İşitsel- görsel dil öğretim yaklaşımı (The audio-visual method): İşitsel görsel dil öğretim yaklaşımı teknolojik aletlerin gelişmesiyle ortaya çıkan bir öğretim modelidir. Bu öğretim modelinde öğenci hem sesleri orijinal olarak duymakta hem de öğrendiği kelime ve diyalogları işlevsel bir şekilde (kısa film-çizgi film- film ve benzeri videolarda) içeren görsel yayınları izlediğinde bu kelimelerle insan davranış ve duygularını özdeşleştirmekte adeta kendisine doğal bir ortam oluşturulmaktadır. (Özgüler, 1983, ss.145-146; el-Huli, 1982, ss.23-25; Hâtır ve diğerleri, 1990, ss.355-357) En önemli özelliği zihnin tüm fonksiyonlarını çalıştırarak öğretmektir. (Doğan, 2012, ss. 195, 198)

Bu yöntemde yazılı materyal azlığı yöntemin eksik yanlarındandır. Ayrıca yazma becerisi ileri düzeylere bırakıldığından bu yöntem de yeterince gelişmez. Ayrıca dilbilgisi kuralları ve okuma becerilerinde de eksiklikler yaşanır. (el-Huli, 1982, s.23; Doğan, 2012, ss.199-200)

5. Okumalı dil öğretim yöntemi (The reading method): Bu yöntem kelimeleri bir dilin yapıtaşları kabul eder. Kelimelerin insan zihnine doğru bir şekilde yerleşmesi, mânâlarının doğru anlaşılması için kelimeleri farklı cümle bağlamları içinde görmek gerekir. Kelimeleri farklı bağlamlarda görmek de yoğun metin okumaları ile mümkündür. $5 \mathrm{Bu}$ yöntemde birebir tercümelerin yerine okunulanın genel olarak doğru anlaşılıp anlaşılamadığı ölçülür, genel tercümeler yapılır. (Demirel, 1990, ss.119-120; Hâtır ve diğerleri, 1990, ss.83,100-103; Doğan, 2012, ss. 159-161, 164) Bu yöntem daha

5 Özcan Demirel, Yabancı Dil Öğretimi: İlkeler, Yöntemler, Teknikler, 2. Bs., Ankara, Usem Yayınları, 1990, s. 120; Mahmud Rüşdi Hâtır, Hasan SSehhate, A. Azazi, el-Medhal ilâ tedrisi'l-lugati'l-Arabiyye ve't-terbiyeti'd-diniyye, Kahire, Dârü’s-Sekafe, 1990/1410, s. 100-103; Candemir Doğan, Sistemik Yabancı Dil Öğretim Yaklaşımı ve Yöntemleri, İstanbul, Ensar Neşriyat, 2012, s. 159 
çok akademik çalışma yapanların ihtiyaç duydukları bir yöntemdir. Zira akademik çalışma yapanlarda en önemli ihtiyaç hedef dildeki metinleri okuyup anlayabilme ihtiyacıdır. Bu yöntemin önemli yanlarından biri de öğrenci hedef dilde okuma-anlama becerisini belli bir ölçüde geliştirdiğinde artık kendi özel çabaları ile de çok ciddi mesafeler alabilir. Öğrencinin okuma becerisini geliştirebilmek için bu çalışmalar bir süre bir öğreticinin nezaretinde yapılmalıdır. Öğrenci okuma eylemini artırdıkça hem kelime hazinesi artar hem de farklı düzey ve kültür alanlarından metinler okuyarak hedef dilin kültürel yapısını öğrenir. Bu yöntemde iletişim ve sözel beceriler yeterince gelişemez, yazma becerileri esnek bir şekilde öğretilir. (Doğan, 2012, ss. 160-163, 167)

6. Seçmeli yöntem (Eclectic method) : Dil öğretiminde tek bir yöntemin yeterli olamayacağı düşüncesinden hareket eden bu yöntem farklı yöntemlerin muhatap kitleye ve bu kitlenin hedeflerine uygun olarak bir araya getirilmesini amaçlar. Zira belli bir yönteme bağlı kalmak muhatap kitlenin hedef ve ihtiyaçlarına göre yetersiz kalabilir veya dil öğrenimi sıkıcı olabilir. Bu yöntemde belirleyici unsur dilbilgisidir. Dilbilgisi öğretimi hedeflenen amaca uygun olarak düzenlenir ve yöntem bunun üzerinden kurgulanır. Bu yönteme göre hedef dilin tam ve doğru anlaşılabilmesi için dilbilgisi kurallarının doğru ve hakkıyla öğretilmesi gereklidir. Bu yöntem ihtiyaç esaslarını göz önünde bulundurarak ortaya çıktığı için teorik genel çözümler üretme yerine pratik çözümler üreterek öğretimin tıkanmasına engel olabilmektedir. Okuma yazma becerilerini geliştirmeyi sonraya bırakmayı ihtiyaca göre öğretimin başında başlatır. Bu yöntemin en büyük sorun farklı yöntemleri birleştirirken bir karmaşanın ortaya çıkma ihtimalidir. (Demirel, 1990, ss.48-49; Deliçay, 2001, s.92; Doğan, 2012, ss. 202-203,206-207, 210-212)

Aşağıda detaylarını vereceğimiz “İstanbul Şehir Üniversitesinde Arapça Öğretim Tecrübesi”ni oluştururken esas aldığımız yöntem bu olmakla beraber yukarıda anlatılan diğer yöntemlerden de ihtiyaca göre istifade ederek bir öğretim yöntemi oluşturduk.

\section{B. Programın hazırlanmasında istifade edilen esaslar}

\section{Müfredat hazırlanması:}

Öğretim uygulamalarında, öğrenmenin hedeflerine uygun doğru yöntem ve müfredatı belirlemek en zor meselelerden biridir. Zira uygun müfredatı belirleyememek öğrenmede zorluklara sebep olmaktadır. Arapça öğretiminde de en önemli meselelerden biri hedef kitleye uygun doğru uygulama ve müfredatı belirleyebilmektir. (Başkan, 1969, s.41; Hâtır ve diğerleri, 1990, ss.83,100-103; Doğan, 2006, ss. 70,8384) Yabancı dil öğretim müfredatı hazırlanırken dört dil becerisinden ${ }^{6}$ her biri dikkate alınmalı ve müfredat bu dört dil becerisine göre hazırlanmalıdır. Aksi takdirde yabancı dil öğrenmek isteyenler bu dört dil becerisinin herhangi birinde zayıf kalırlar bu da öğrencilerin kendilerine olan özgüvenlerini kaybetmelerine sebep olur. (Demirel, 1990, s.23; Hâtır ve diğerleri, 1990, ss.63-64; Kaçar, 2006, ss.121122)

Arapça öğretiminde özellikle Arapçayı iletişim dili olarak öğrenen kimselerde dört beceriyi geliştirmek dikkate alınmalı ve müfredat buna göre hazırlanmalıdır. Arapça farklılıkları ve üslupları itibarı ile zengin bir dildir. Bu durum Arapça öğretimi ile ilgili müfredat hazırlanmasında karşlaşllan zorlukların temel sebebidir. (el-Battal ve Belnap, 2012, s.52)7 Zira toplumsal iletişim araçlarında kullanılan Arapça ile

Dört dil becerisi; Konuşma, Dinleme, yazma ve okuma.

Amerika Birlesik Devletlerinde entelektüel ve akademik dil olarak isimlendirilen fasih Arapçaya Modern Standart Arabic ismi verilmiştir. Günlük konuşma lehçelerinin toplum ve öğrenciler nazarında öneminin artmasıyla birlikte, Amerika'da da bu iki müfredatı mezc etme ile ilgili çalışmalar başlamıştır. Bkz. Mahmoud al-Battal - R. Kirk Belnap, "a.g.m.”, s. 52- 
ilmî-edebî yazılarda ve İslami metinlerde kullanılan Arapça arasında da farklılıklar vardır. (Müezzin, 2016, s.106) ${ }^{8}$ Bu ikisini bir bütünlük içerisinde birleştiren bir müfredat hazırlamak meşakkatli bir iştir. Bu zorluğun farkında olan Riyad Dil Enstitüsü, hem konuşma dilini hem de akademik dili öğrettiği öğretim sürecini iki ylllık bir öğretim olarak planlamıştır. (Civelek, 1998, ss.237-239) Bugün Türkiye'de İlahiyat fakültelerinde ve İslami ilimler fakültelerinde Arapça hazırlık sınıfı bir yıllık bir öğretim sürecine sahip olduğundan bu süre içerisinde hem iletişim dilini hem de İslami metinlerin dilini öğretmeye yönelik bir müfredatın hazırlanmasının zorluğu ortadadır.

Eğitim-Öğretim amaçlarına uygun müfredat hazırlandıktan ve öğrenci kitlesine uygun yöntem belirlendikten sonra yabancı dil öğretiminin etkili olabilmesi için hem öğrenme ortamının buna uygun hale getirilmesi hem de öğretim araç ve gereçlerinin döneme ve günün gereklerine uygun bir şekilde kullanılması gerekmektedir. Bunun yanı sıra öğretmen sadece kendi öğretimini dikkate almamalı, öğrencilerinin öğrenme durumlarını tespit ederek gerekirse ek çalışmalar yapmalı/yaptırmalı ve ihtiyaç halinde buna uygun materyaller üretmelidir. (Ekmekçi, 1983, ss.23-26; Demirel, 1990, ss.26-27; Hâtır ve diğerleri, 1990, ss.193-197) Ayrıca Arapça öğretim setlerindeki uyumsuzluk müfredat ve yönteme uygun olarak giderilmeli gramer, pratik ve metin kitapları birbiri ile uyumlu bir hale getirilmelidir. (Civelek, 1998, ss.279)

Müfredat; yöntem ve ders materyalleri belirlendikten sonra hazırlanmalıdır. Çünkü eğitim bilimcilere göre öğrencinin öğrenmesini etkileyen en önemli ilkelerden biri de öğretim etkinliklerinin ylllı ve günlük olarak planlanmasıdır. (Demirel, 1990, ss.23-24; Usta, 2012, 318-319) Planlama müfredata, hedeflere ve öğrencinin öğrenme şartlarına uygun olmalıdır.

1.1. Gramer: Arapça öğretiminde özellikle tartışlan konulardan biri de gramer öğretimi ${ }^{9}$ olduğu için ona bu makalede ayrı bir başlık açtık. Dil öğretiminde gramer kuralları, farklı düzeylere ve hedeflere uygun olarak müfredata yerleştirilmelidir. (Civelek, 1998, ss.239,268-270; Suleyti, 2002, ss.39-40; Kaçar, 2006, ss.130-131) Arapçayı iletişim dili olarak öğrenen öğrencilere ayrıntılı sarf-nahiv bilgileri verilmemeli, verilen dilbilgisi kuralları teorik değil işlevsel olmalıdır. (Suleyti, 2002, ss.34,62,114-125; Doğan, 2006, ss.79,82) Diğer taraftan gramerin daha ayrıntılı anlatıldı̆̆ı İslami ilimler öğrencileri için gramer bilgileri diğer dil becerilerini destekleyecek tarzda ve konuların birbiriyle uyumlu bir şekilde öğretilmesine özen gösterilmelidir.(Suleyti, 2002, ss.62-64; Soyupek, 2004, ss.104-107; Kaçar 2006, ss.128-130) Ayrıca gramer kuralları ögretilirken edebî metinlerde bu kuralların uygulaması yapılmalıdır. Böyle yapıldı̆̆ı takdirde kurallar öğrencilerin nazarında canlı bir kurala dönüşecektir. Arapçayı öğrenmek isteyenlere dil öğretilirken mutlaka gerek geçmiş gerek günümüze ait edebi metinlerle bir irtibat kurulmalıdır. (Hafacî, 2001, ss.170-172; Suleyti, 2002, ss.68-69) Eğer gramer öğretilirken bu kurallar edebi metinlerle canlı bir hale getirilmezse gramer kuralları anadili Arapça olan öğrenciler için bile sıkıcı bir kurallar bütününe dönüşecektir. ${ }^{10}$

53; Ayrıca fasih Arapçanın öğretiminde de, toplumsal iletişim araçlarında kullanılan dil ile ilmî-edebî yazılarda ve İslami metinlerde kullanılan dil arasında farklılıkların olduğuna ve ikisinin öğretim yöntemlerinin farklı olduğuna dair bkz. Ahmet Derviş Müezzin, "Anadili Arapça Olmayanların Arapça Öğretiminde Başarılı Yöntem ve Stratejiler", Kahramanmaraş Sütçü İmam Üniversitesi İlahiyat Fakültesi Dergisi, 2016, cilt: XIV, sayı: 28, s. 106

8 Bununla ilgili yapılan bir araştırma ve çalışma için bkz. http://www.m-a-arabia.com/vb/showthread.php?p=26585, ileşim tar. 22.10.18, saat, 11:55

$9 \quad$ Bu konu ayrı ve müstakil bir makale konusu olabilir. Fakat biz burada makalenin yazılış amacını ve aynı zamanda ikinci bölümünü olușturan “Arapça Öğretiminde İstanbul Şehir Üniversitesi Tecrübesi”nin anlatımında gerekli gördüğümüz kadarıyla bu konuya değindik. Gramer öğretiminin zorlukları ve yeni öğretim yöntem ve usûl teklifleri için bkz. Zabiyye Saîd Suleyti, Tedrisü'n-nahvi'l-Arabi fî dav'i'l-itticahati'l-hadise, Kahire, ed-Dârü'l-Mısriyyetü'l-Lübnâniyye, 2002/1423

${ }_{10} \mathrm{Bu}$ konuda Katar'da Arap öğrencilere yapılan bir araştırmanın değerlendirilmesi için bkz. Zabiyye Saîd Suleyti, Tedrisü'n-nahvi'l-Arabi fi dav'i'l-itticahati'l-hadise, Kahire, ed-Dârü'l-Misriyyetü'l-Lübnâniyye, 2002/1423, s. 34 
1.2. Sinavlar: Yabancı dil öğretiminin ve hazırlanan müfredatın en önemli ayaklarından biri de sınavlardır. Sınavların ölçme-değerlendirme aracı olmalarının yanında öğretici fonksiyonları da vardır. Öğrenci girmek zorunda olduğu sınavlar sebebiyle sınav öncesi konu ve kelime tekrarları yapar. Girilen sınav neticesine göre de eksiklerini tespit eder, bu eksikleri gidermeye çalışır.(el-Huli, 1982, s.23; Demirel, 2003, s.116; Özdemir, 2004, ss.32-34) Bu yüzden yabancı dil öğretiminde mümkünse verilen her konuyu küçük bir sınavla değerlendirmek konunun ne kadar anlaşıldığının tespiti açısından oldukça önemlidir. Bu kısa sınavlar da öğrencinin başarılı sayılmasında önemli bir etkiye sahip olmalıdır. (Özdemir, 2004, ss.32-34; Kaçar, 2006, s.127)

1.3. Yurt dışı eğitimi: Öğrencilerin Arapça dil becerilerinde daha üst bir dil seviyesi elde etmeleri ve öğrendikleri dili doğal ortamında uygulayabilmeleri için yurtdışı eğitimi önemli bir etkendir. (el-Battal ve Belnap, 2012, s.51; Başkan, 1969ss.76-79) Yurtdışı eğitimi ile öğrencinin öğrendiği dil becerilerini doğal ortamında kullanması sağlanır. Ayrıca yurt dışındaki öğretim müfredatı yurt içinde verilen Arapça öğretim müfredatı ile uyumlu ve bu müfredatın devam ettiricisi olmalıdır.

\section{Bölüm}

\section{Arapça öğretiminde İstanbul Şehir Üniversitesi tecrübesi ${ }^{11}$}

Çalışmamızın bu kısmında yukarıda anlattığımız ilke, esas ve yöntemler ışığında İlahiyat/İslami İlimler Fakültesi ve diğer fakülte öğrencilerinin Arapça'ya olan ihtiyaçlarının ve Arapça öğreniminden kaynaklanan hedeflerinin karşılanması için Şehir Üniversitesindeki öğretim tecrübesinden bahsedeceğiz.

Şehir Üniversitesinde Arapça öğretiminin planlaması Arapça öğrenmeye ihtiyaç duyan/istekli olan öğrencilerin hedef, amaç ve ihtiyaçlarına göre yapılmıştır. İslami İlimler Fakültesi öğrencilerinin Arapça öğretim programı, haftalık ders saatinin dağılımı, belirlenen ders kitapları, ölçme değerlendirme yöntemleri/ölçütleri ve kültürel aktiviteleri kendine özgü olarak hazırlanmıştır. İslami İlimler Fakültesi dışındaki bölüm öğrencilerinin programı ve ders materyalleri ise bu öğrencilerin ihtiyaç ve hedeflerine göre belirlenmiştir. ${ }^{12}$

Bu açıklamalardan da anlaşılacağı üzere Arapça öğretimindeki hedef kitle;

a. İslami İlimler Fakültesi öğrencileri

b. Diğer fakültelerin öğrencileri olmak üzere iki kısımdır.

\footnotetext{
${ }_{11} \quad$ Bu program Dr. Özgür Kavak koordinatörlüğünde Dr. Ali Tülü, Muhammed Raşid Derşevi ve Dr. Abdurrahman Haraş tarafından hazırlanmıștır.

12 Programın hazırlanmasında öğrenci ihtiyaç ve maksadını dikkate almanın gerekliliği ve bunun başarı daha fazla başarı sağladığına dair bkz. Özcan Başkan, Yabancı Dil Öğretimi : İlkeler ve Çözümler, İstanbul, İstanbul Üniversitesi Edebiyat Fakültesi, 1969, s. 41; Mahmud Rüşdi Hâtır, Hasan Şehhate, A. Azazi, el-Medhal ilâ tedrisi'l-lugati'lArabiyye ve't-terbiyeti'd-diniyye, Kahire, Dârü's-Sekafe, 1990/1410, s. 23-24, 63-64; Hasan Soyupek, "ilahiyat Fakültelerinde Arapça Öğretiminin Mesleki Öğretim Açısından Önemi ve Yöntem Sorunu”, Süleyman Demirel Üniversitesi İlahiyat Fakültesi Dergisi, 2004/1, sayı: 12, s. 110-111; Candemir Doğan, Sistemik Yabancı Dil Öğretim Yaklaşımı ve Yöntemleri, İstanbul, Ensar Neşriyat, 2012, s. 41, 44.
} 


\section{A. İslami İlimler Fakültesi öğrencilerine uygulanan program:}

Bu başlık altında İslami İlimler Fakültesi öğrencilerinin hedef ve ihtiyaçlarının belirlenmesinden ve onlar için hazırlanan program ve çalışmalardan bahsedilecektir.

\section{1. İslami İlimler Fakültesi öğrencilerinin Arapça öğrenimindeki hedefleri/ihtiyaçları:13}

İslami İlimler Fakültesi öğrencilerinin Arapça öğrenimindeki hedef ve ihtiyaçlarından bazıları şunlardır;

1.1. Tefsir, hadis, fikıh, kelam gibi şer‘i ilimlerin temel eserlerini okuyup anlayabilmek

1.2. Bu temel eserlerdeki bilgileri yaşadıkları dönemin şartlarına uygun olarak anlaşılır ve kolay bir dille günümüze taşımak.

1.3. Bu temel eserlerden bazılarını kendi diline tercüme etmek.

1.4. Klonlama, organ nakli gibi günümüz meselelerinin İslam Fıkhı açısından değerlendirilebilmesi amacıyla temel eserlerdeki meselelerle karşılaştırmalar yapmak.

1.5. Arapça konuşan milletlerin bireyleri ile güçlü bir iletişim kurmak ve görüş alışverişinde bulunmak.

$\mathrm{Bu}$ hedef ve amaçlar doğrultusunda İslami İlimler Fakültesi öğrencilerinin ders materyalleri ve programı, günümüz öğretim tekniklerine uygun olarak sınıf içi ve sınıf dışı aktivitelerle yukarıdaki hedefleri yerine getirebilmek üzere hazırlanmıştır.

\section{Dil öğretimindeki dört temel becerinin belirlenen öğretim programındaki dağılımı:}

Hazırlanan programda dil öğretimindeki dört temel beceri; konuşma, dinleme, okuma ve yazma dikkate alınmış ve hem program buna göre düzenlenmiş hem de ders materyalleri buna göre belirlenmiştir. Belirlenen ders materyalleri ve düzenlenen program anlatılırken bunların dört temel beceriye katkılarına da değinilecektir.

2.1. Ders materyalleri: Ders materyallerimizi yukarıda bahsedilen dört temel beceriye hizmet edecek şekilde belirlemeye çalışırken konuşma becerisi için belirlediğimiz eseri temele aldık. Diğer materyalleri bunun etrafında birbirine uyumlu olacak, birbirini destekleyecek ve öğrenciye doğal olarak bildiklerini tekrar ettirecek şekilde düzenledik. Belirlediğimiz ders materyalleri ve özellikleri şöyledir;

2.1.1. el-Kitap : Mahmut el-Batal, Abbas et-Tonsî ve Kristen Brustad tarafından hazırlanan. üç ciltlik eserin ikinci baskısı okutulmaktadır. Arapça dil öğretimindeki dört temel beceriye de hizmet etmekle birlikte özellikle konuşma becerisine, kelime ve terkip öğretimine büyük katkısı olan bu eser ders materyali olarak esas alınmış diğer eserler hususî amaçlarına hizmet edecek şekilde bu esere uyumlu olarak düzenlenmiştir. Adı geçen eserin Arapça öğretimindeki usulü, üslubu ve yazarlarının öğretim felsefesi eseri benzerlerinden farklı kılmış ve kanaatimizce birçok öğretim serisinden de üstün kılmıştır. Eser gerek seçtiği kelime ve terkipleri gerek sınıf içi, sınıf dışı aktiviteleri ve ödevlendirmeleriyle,

13 İslami İlimler eğitimi alanların Arapça'ya ihtiyaç duyma nedenleri hakkında bkz. Abdurrahman Özdemir, "İlahiyat Fakültelerinde Arapça Öğretiminin Gerekliliği, Karşlaşlan Sorunlar ve Çözüm Önerileri”, Sakarya Üniversitesi İlahiyat Fakültesi Dergisi, 2004, sayı: 10, s. 27-28; Hasan Soyupek, "İlahiyat Fakültelerinde Arapça Öğretiminin Mesleki Öğretim Açısından Onemi ve Yöntem Sorunu”, Süleyman Demirel Universitesi İlahiyat Fakültesi Dergisi, 2004/1, sayı: 12, s. 100103; H. İbrahim Kaçar,, "İmam-Hatip Liseleri ve İlahiyat Fakültelerinde Arapça Öğretimi Üzerine”, Din Ĕgitimi Araştırmaları Dergisi, 2006, sayı: 17, s. 118 
Arapça’yı sadece sınıf içi değil sınıf dışında da öğrencinin yaşadığı bir realiteye çevirmiştir.(el-Battal ve Belnap, 2012, s.XIX) Eserin müellifleri, dinleme becerisinin geliştirilmesi için her ünitede öğretilmesi hedeflenen kelime müfredatını içeren ses/diyalog/anlatım dosyaları ile beraber yine dinleme becerisinin geliştirilmesi için ünitedeki yeni kelimeleri ve ünitenin üst başlığı olan temayı içeren bir video hazırlamışlardır. Eser her ne kadar dil öğretimindeki dört beceriye hizmet etse de biz bu eseri kullanırken Arap asıllı hocalarımızla özellikle konuşma becerisi üzerinde yoğunlaştık. Bu öğretim serisini farklı kılan noktalardan biri de kitaplardaki metinlerin konu anlatımı için kurgulanmış metinler olmayıp gazete, dergi ve kitaplardan derlenmiş gerçek metinler olmaları, ayrıca metinlerin harekesiz olarak sunulmalarıdır.

Eserin İslami İlimler Fakültesi öğrencilerinin hedeflerine karşıllk veremediğini düşündüğümüz hususları ise belirlediğimiz diğer materyallerle tamamladık.

2.1.2. En-Nahv ve's-Sarf: Arapça gramerinin önemine olan inancımızdan ve gramerin bir dilin tesisinde omurga olduğu düşüncesinden(Usaylî, 2016, s.13; Doğan, 2012, ss.69-70) hareketle gramer konusuna özel bir ihtimam gösterdik ve el-Kitap’ta bulunan gramer bilgisiyle yetinmeyip en-Nahv ve esSarf isimli iki kitap okuttuk. ${ }^{14}$ Bu iki eser Camiatü'l-İmam Muhammed b. Su'ud el-İslamiyye'nin Arapça öğretimi için hazırladığı setin sarf ve nahiv konularını içeren eserleridir. Silsile Dr. Abdullah el-Hamid editörlüğünde hazırlanmıştır. Hem sarf hem de nahiv için hazırlanan kitaplar üçer cilttir. Eserde nahiv konuları çok fazla ayrıntıya girilmeden anlatılmıştır. Her bir ünitenin başında, ünitenin konusu olan gramerin uygulamasının yapılabilmesi için konuya uygun bir metin hazırlanmış, ayrıca ünite alıştırmalarla desteklenmiştir. Biz bu eserleri seçerken Sarf-Nahiv ilimlerini ayrı iki ders olarak ele almayıp ikisini beraber gramer dersi olarak düşündük. Eseri hazırlayan üniversitenin sitesinde bu setin pdflerinin ücretsiz yayınlamasından da istifade ederek Sarf-Nahiv kitaplarının konularını el-Kitap'daki gramer konularına göre yeniden düzenledik. ${ }^{15}$ Böylece öğrenci hem gramer dersinde öğrenmiş olduğu gramer konusunun el-Kitap’n okutulduğu derslerde de uygulamasını yapma imkanı kazanmış oldu. Bu düzenlemenin bir diğer faydası da öğrencinin iki farklı derste iki farklı gramer konusuyla karşılaşmamasıdır. ${ }^{16}$ Arapça'nın gramerine bu kadar önem vermemizin temelinde öğrencilerimizden fakültenin ilk yıllarından itibaren farklı ilim dallarından Arapça klasik metinleri okumalarını istememizdir. Özellikle İslami ilimlerin teşekkül ettiği ilk dönemlere göz attığımızda hususen tefsir kitaplarının - Ebu Zekeriyya Yahya el-Ferrâ'nın (ö. 207) Maani'l-Kur'an'ı, Ebu İshak ez-Zeccâc'ın (ö. 311) Maani'l-Kur'an ve I'rabuhu v.b.- gramer ve lugavi bilgilerle dolu olduğunu görmekteyiz. Diğer yandan ana dili Arapça olmayan kimselerin bu dili öğrenmeleri ve özellikle yazma becerilerini geliştirebilmeleri için Arap dili gramerini bilmeleri gerektiğine inanıyoruz. (Usaylî, 2016, ss.21-22)

2.1.3. el-Kıraatü'l-Arabiyye li'l-Müslimin: Bu seri Mahmud İsmail Sînî, Mahmud Hüseyin Ebû'lFettah, Enver Reşid Bedreddin, Mustafa Ömer Humeyde ve Ahmed Abdülvehhab eş-Şa'rani tarafından üç cilt olarak hazırlanmıştır. İslami İlimler Fakültesi öğrencileri Kur’an-ı Kerim’in, Hadis-i şeriflerin ve Arapça klasik metinlerin anlaşılmasında kendilerine anahtar olacak bir dili öğrenmeye ihtiyaç duymaktadırlar. Öğrencilerimizin bu ihtiyacına cevap vermek ve bu alandaki gayelerine ulaşmalarını

\footnotetext{
$14 \quad$ Ayrıca Dilbilgisi kurallarının çağdaş setlerde olduğu şekliyle değilde kuralları örneklerle açıklayan dilbisi kitaplarından öğrenmenin daha etkin olduğu için bkz. Candemir Doğan, Sistemik Yabancı Dil öğretim Yaklaşımı ve Yöntemleri, İstanbul, Ensar Neşriyat, 2012, s. 54-55

15 Benzer görüşler için bkz. Mahmud Rüşdi Hâtır, Hasan Sehhate, A. Azazi, el-Medhal ilâ tedrisi'l-lugati'l-Arabiyye ve't-terbiyeti'd-diniyye, Kahire, Dârü's-Sekafe, 1990/1410, s. 181-182; Yakup Civelek, Türkiye'de Arapça Öğretimine Dair Bazı Teklifler -Riyad Arap Dil Enstitüsü Örneği-, Yüzüncü Yıl Üniversitesi İlahiyat Fakültesi Dergisi, 1995-1998, cilt: II, sayı: 2, s. 279

16 Bir seferde bir yapının öğrenilmesinin gerekliliği için bkz. Özcan Demirel, Yabancı Dil Öğretimi; Dil Pasaportu, Dil Biyografisi, Dil Dosyası, Pegem Yayınları, Ankara, 2003, s. 26
} 
sağlayabilmek için seçtiğimiz bu seriyi temel eserleri anlamaya giriş kitabı olarak düşündük. Bu eser İslami ilimlerin farklı dallarından metinler içermekte ve bunun neticesi olarak başta Kur'an-ı Kerim ve hadis-i şerifler olmak üzere İslami ilimlerde var olan birçok kelime, terim ve ıstılahı içermektedir.(Sînî, Ebû'l-Fettah, Bedreddin, Humeyde ve eş-Şa'ranî, 1995, ss.o-و) Bu seri öğrencilere İslami ilimlerin terimlerini öğretmekle birlikte onların okuma becerisini geliştirmekte ve Arapça metinleri doğru okumalarına yardımcı olmaktadır. ${ }^{17}$

2.1.4. Arabiyyetï Vesâili'l-I'lam: Birçok dil kursunda, enstitüde ve üniversitede Arapça okutulmakta ve çok sayıda öğrenci buralardan mezun olmaktadır. Fakat Arapça basın-yayın diline dair ders saatlerinin azlığı sebebiyle birçok öğrencinin bu alanda zayıf kaldıkları ve bu sebeple gerek Arapça yayınları izlemeye gerek okumaya cesaret edemedikleri görülmektedir. (Deliçay, 2011, s.10) Öğrencilerimizin dinî ve şerî̀ ilimlere ait terimleri ve ıstılahları/kavramları öğrenmesinin yanı sıra Arap âleminin meselelerine Arapça kaynaklarından vakıf olması amacıyla el-Kitap’taki kelimeleri ve müfredatı destekleyecek aynı zamanda bunu geniş̧letecek tarzda bu dersi koyduk. Dersin, öğrencilerin özellikle dinleme becerilerini geliştireceği de bir gerçektir.

Bu ders için yayın organlarından siyasi, içtimaî ve kültürel alanlar başta olmak üzere birçok alanda sesli ve görüntülü materyaller aldık. Bu materyallerin içerdikleri kelimelerin, kavramların ve konuların anlaşılmasına yardımcı olacak çalışma kâğıtları hazırladık. Bu materyalleri seçerken öğrencilerin seviyelerini göz önünde bulundurduk ve öğrencileri seviyelerine göre Arapça yayınları takip etmeye teşvik ettik. ${ }^{18}$

2.1.5. el-Kitabe; imla-inşa: Öğrencinin kelimeleri duyması, okuması ve telaffuz etmesinden sonra dil öğretimimizde öğrenci bu kelimeleri ve kelimelerle oluşturacağı metinleri yazma aşamasına gelmiştir. Yazma becerisi, yabancı dil öğretiminde geliştirilmesi öncelikle kelime yazımıyla başlar. Sonra bu kelimelerle basit cümleler kurulur ve akabinde paragraf yazımı ile devam eder. Nihayetinde çeşitli metin türleri (deneme, biyografi, otobiyografi, makale vs.) yazmakla devam eder. Bunun için öğrenciler öncelikle harflerin yazımını, yazım kurallarını öğrenirler. Bizler İslami İlimler Fakültesinde öğrencilerimize yazım kurallarını öğrettikten sonra her bir dönem için onlardan ortalama 150 kelimeden oluşan 10 yazı ödevi istiyoruz. Bu yazı ödevleri sorumlu ders hocası tarafindan kontrol edilmekte "likai ferdî/birebir görüşme” dediğimiz öğrenci-hoca görüşmesinde değerlendirilmektedir. Öğrencilerin yazım bilgisi, kelime ve söz dizimi yanlışları ilgili hocalar tarafından öğrenci ile müzakere edilmekte ve metinde varsa yanlışlar düzeltilmektedir.

2.2. Ders programı: Öğrencinin Arapça programına dâhil olup bu programdan mezun olmasına kadar geçen süre içerisindeki program aşağıdaki gibi planlanmıştır;

2.2.1. Seviye tespit sınavi: Fakültemize kayıt yaptıran öğrenci, Arapça eğitimine başlamadan önce bir seviye tespit sınavına girer. Öğretim kadromuz tarafından hazırlanan sınav soruları okutmaya karar verdiğimiz müfredat ve ders materyallerinden hazırlanır. Bunu yaparken okutulması düşünülen her bir kur materyalinden aynı oranda soru hazırlar ve bu soruları kur sırasına göre sınav kağıdına alt kurdan

17 Akademik çalışma yapacaklar ve İslami ilimler alanında çalışma yapacaklar için en önemli becerinin okuma becerisi olduğu ve mesleki alanla ilgili yeterliliklerinin önemi için bkz. Hasan Soyupek, "İlahiyat Fakültelerinde Arapça Öğretiminin Mesleki Öğretim Açısından Önemi ve Yöntem Sorunu”, Süleyman Demirel Üniversitesi İlahiyat Fakültesi Dergisi, 2004/1, sayı: 12, s. 111-112.

18 Görüntülü materyallerden yararlanma şekli için bkz. Özcan Demirel, Yabancı Dil Öğretimi: İlkeler, Yöntemler, Teknikler, 2. Bs., Ankara, Usem Yayınları, 1990, s. 100-104; Yakup Civelek, Türkiye’de Arapça Öğretimine Dair Bazı Teklifler -Riyad Arap Dil Enstitüsü Örneği-, Yüzüncü Yıl Üniversitesi İlahiyat Fakültesi Dergisi, 1995-1998, cilt: II, sayı: 2, s. 279. 
üst kura doğru sıralarız. Böylece öğrenci kolaydan zora doğru bir sıralama görmekte ve kendi seviyesine uygun soruları çözebilmektedir. Bu imtihan neticesinde öğrencilerimizin kur seviyelerini tespit eder ve seviyelerine uygun olarak sinıfları oluştururuz.

2.2.2. Toplam ders saati: Zorunlu Arapça öğretim programımız yedi yüz saati üniversitemizde, yüz kırk saati yurt dışında olmak üzere 840 saattir. Öğretimimizin her bir kuru yüz kırk saatten olmak üzere $5^{+1}$ kur şeklinde planlanmıştır. Öğrencilerimiz seviyelerine göre bu kurlardan biriyle Arapça öğretimine başlar. Öğrencinin başladığı kura göre haftalık ders saati 10 saatten 20 saate kadar değişmektedir. Yurt dışı programına ise tüm öğrencilerimiz gönderilmekte ve son 140 saatlerini orada tamamlamaları sağlanmaktadır. Ayrıca bu 700 saatlik program saat saat planlanmış ve ders planı şeklinde hazırlanmıştır. ${ }^{19}$

2.2.3. Ölçme-değerlendirme: Yapılan öğretim programının en önemli esaslarından birini ölçme değerlendirme oluşturmaktadır. Biz ölçme değerlendirmemizi şu şekilde oluşturduk;

2.2.4. Ev ödevleri: Her dersin öğreticisi kendi dersi ile ilgili ev ödevleri vermekte ve bu ödevleri inceleyip değerlendirdikten sonra puanlamaktadır. Dönem sonu her öğreticiden verdiği puanlar toplanır ve toplanan ortalaması öğrencinin ev ödevi notu olur. Ev ödevleri puanlarının genel geçme puanındaki ağırlığı \% 9 oranındadır.

2.2.5. Yazı ödevleri: Öğretilecek konu ve müfredata göre belirlenip her dönem için sene başında ilan edilen 10 konu hakkında öğrencilerimiz en az 150 kelimeden oluşmak üzere 10 yazı ödevi hazırlamaktadır. Yazı ödevlerinden sorumlu öğreticilerimiz bu ödevleri değerlendirmekte ve notlandırmaktadır. Bu yazılarla ilgili öğrencilere bildirilmesi gereken görüş ve öneriler birebir çalışma esnasında ulaştırılmakta ve bu yazılar gerektiğinde birebir çalışmada birlikte değerlendirilmektedir. Yazı ödevlerinin ortalamasının genel geçme puanındaki ağırlığı \% 6 oranındadır.

2.2.6. Kısa sınavlar: Öğrencilerimiz her dönem, on beş yirmi dakikalık on adet kısa sınava tabi tutulmaktadır. Bu sinavlarla öğrencilerin hafta boyunca öğrendiği dersleri tekrar etmesi ve eksiklerini belirlemesi hedeflenmektedir. Kısa sınavların ortalamasının genel geçme puanındaki ağırlığı \% 12 oranındadır.

2.2.7. Video projesi: Öğrenci konusu kendisine daha önceden verilmiş olan bir video hazırlar ve bu videoda ilgili konuyu anlatır. Bunu yaparken yardımcı materyaller ve görseller kullanabilir. Öğrenci hazırladığı videoyu belirlenen tarihte sorumlu hocaya teslim eder. Bu videolar ilgili öğretici grubu tarafından değerlendirilir. Video projesinden alınan puanın genel geçme puanındaki ağırlığı \% 6 oranındadır.

2.2.8. Sözlü sunum: Öğrenci kendisinin belirlediği bir konu veya şahıs hakkında sözlü bir sunum hazırlar ve bunu sınıfta sunar. Bu sunumlar ders öğreticisi tarafından değerlendirilir. Sözlü sunum puanının genel geçme puanındaki ağırlığı $\% 3$ oranındadır.

2.2.9. Vize sınavı: Öğrenci dönem ortasında sadece yazılı olarak yapılan vize sınavına girer. Bu sınav puanının genel geçme puanındaki ağırlığı \% 24 oranındadır.

19 Ders planının hazırlanmasının yöntemi, gerekliliği ve faydaları için bkz. Özcan Demirel, Yabancı Dil Öğretimi: İlkeler, Yöntemler, Teknikler, 2. Bs., Ankara, Usem Yayınları, 1990, s. 23-24, 149-150. 
2.2.10. Final sınavı: Final sınavı dönem sonunda yazılı ve sözlü olarak yapılır. Yazılı sınav puanının genel geçme puanındaki ağırlı̆̆ \% 34 oranındadır. Finaldeki sözlü sınavınn genel geçme puanındaki ağırlığı ise \% 6 oranındadır.

3. Belirlenen müfredatı destekleyecek programlar: Belirlenen müfredatın daha iyi anlaşılabilmesi ve öğrenilebilmesi için bir takım ek çalışmalar ve programlar hazırladık. Bu çalışma ve programlar şöyledir;

3.1. Klasik metinlerin okunması: Arapça gramer kurallarının yerleşmesi ve gramer kurallarının yazıldığı klasik eserlerin üslubuna alışmaları için öğrencilerimize 700 saatlik zorunlu Arapça derslerinin yanı sıra seçmeli dersler olarak Emsile, Bina, Maksud, Avamil, Ecrûmiyye şerhi et-Tuhfetü's-seniyye, İzharu'l-esrar ve belağat okutulmaktadır. ${ }^{20}$ Öğrenciler sarf ilmine dair klasik metinleri okuyarak kelimenin kökünü ve Arapça'da kök kelimeden nasıl kelime türetildiğini ve türemiş kelimelerdeki anlam farklılıklarını/inceliklerini öğreneceklerdir. Nahiv ilmine dair klasik metinler ile belağata dair metinleri okuyarak kelime ve cümlelerin inceliklerine vakıf olacak, kelimelerin cümledeki konumlarına göre kazandıkları anlam inceliklerini öğreneceklerdir.

3.2. Çalışma kâğıtları: el-Kitabın alıştırma çeşitliliğine rağmen özellikle yeni öğrenilen kelimelerin ve kuralların tekrarlarla öğrencinin zihnine daha iyi yerleşmesi için ders esnasında ve dışında çözülmek üzere için yaklaşık 250 çalışma/alıştırma kâğıdı hazırlanmıştır. ${ }^{21}$

3.3. Birebir çalışma: Her sınıfın sorumlu hocası sınıftaki her bir öğrenci ile haftalık olarak 15-20 dakika birebir çalışmaktadır. Sorumlu hoca bu görüşmede hem öğrencinin öğrenim seyrini takip etmekte hem de önceden kararlaştırılan bir konunun veya öğrenci tarafından okunan bir hikâyenin Arapça olarak anlatılmasını istemektedir. ${ }^{22} \mathrm{Bu}$ çalışma öğrencinin hem konuşma hem de okuma temel becerilerini geliştirmesinin yanında ona özgüven ve öğrendiği meseleleri Arapça müzakere etme gücü vermektedir. ${ }^{23}$

3.4. Sınıf dışı kültürrel aktiviteler: Resmi ders müfredatımız haricinde öğrencilerimizle hocalarımız "Arapça Saati” başlı̆̆ altında farklı etkinlikler düzenlemektedir. Bu etkinlikler tiyatro, konferans, Arapça yarışmaları ve Arapça münazara gibi etkinliklerdir. Bunun haricinde öğrencilerimize günlük yarım saat Arapça seyretme/dinlemeyi tavsiye ettik. Bu çalışmanın sonunda gerek bizim tavsiyelerimizden gerekse öğrencilerimizin seyredip diğer arkadaşlarına tavsiye ettikleri görsel materyallerden güzel bir liste oluştu ve öğrencilerimiz bu listeyi sosyal medya hesaplarından yayınladılar. ${ }^{24}$

Buraya kadar anlattığımız program İslami İlimler Fakültesi öğrencilerine uyguladığımız programdır. Diğer fakülte öğrencilerine ise farklı bir program uygulamaktayız. Onlara uygulanan program ise aşağıdaki gibidir.

\footnotetext{
$20 \quad$ Fıkıh, Hadis gibi temel İslam İlimlerinde de bu yöntem takip edilmekte ve öğrencilerimize seçmeli dersler olarak bu ilimlerden de klasik metinler okutulmaktadır.

${ }_{21} \quad$ Eğitimi farklı materyallerle geliştirme ve çalışma yapraklarının faydası için bkz. Candemir Doğan, Sistemik Yabancı Dil Öğretim Yaklaşımı ve Yöntemleri, İstanbul, Ensar Neşriyat, 2012, s. 39-40

22 Öğrencinin okuduğu hikâyelerin konuşması için teşvik edici bir unsur olmasıyla alakalı bkz. Mahmud Rüşdi Hâtır, Hasan Şehhate, A. Azazi, el-Medhal ilâ tedrisi'l-lugati'l-Arabiyye ve't-terbiyeti'd-diniyye, Kahire, Dârü's-Sekafe, 1990/1410, s. 139-140

23 Bu çalışma fakültemizin az sayıda öğrenci alması ile ilgili bir durum değildir. Zira üniversitemizde ingilizce hazırlık sınıflarına yıllık 700-800 öğrenci alınmakta ve bu öğrencilerin hepsi ile bu çalıșma yapılmaktadır.

24 Bkz. https://sehirisifkulubu.com/2018/02/19/izleyerek-arapca-arapca-izleme-link-listesi/. Erişim tarihi: 12.11.18, sa.
} 12:51 
B. Diğer fakülte öğrencilerine uygulanan program: İslami İlimler Fakültesi dışındaki fakülte öğrencilerinden Arapça öğrenmeye ilgi ve ihtiyaç duyan öğrencilere yönelik de bir program hazırladık. Bu programı hazırlarken öğrencilerin ihtiyaç ve hedefleri ile alabilecekleri ders saatini göz önünde bulundurduk. Bu öğrencilerin Arapça eğitim programı ve gerçekleştirilmek istenilen hedefler ise şöyledir;

\section{1. İslami ilimler dışındaki öğrencilerin Arapça öğrenimindeki hedefleri/ihtiyaçları:}

İslami ilimler Fakültesi dışındaki öğrencilerin Arapça öğrenmedeki hedefleri ve ihtiyaçlarından bazıları şunlardır;

1.1. Kur'an-ı Kerim’i anlamak ve bazı dini kaynakları okuyabilmek.

1.2. Türkiye'nin Ortadoğu'daki etkinliğinin artmasından sonra hem Arap hem de Türk tarafında siyasi, iktisadi ve toplumsal olmak üzere karşılıklı çalışma alanlarının oluşması Arapça öğrenimini önemli bir ihtiyaca dönüştürmesi(Kaçar, 2006, s.118) ve öğrencilerin bir kısmının bu ihtiyaca cevap vermek istemesi.

1.3. Türkiye'de ve Arap-İslam âleminde Arapça konuşan kimselerle iletişimin kişinin hem kendisine hem de coğrafyanın problemlerini çözmeye fayda sağlaması.

1.4. Ortadoğu'nun uluslararası ilişkilerdeki yeri, özellikle Ortadoğu yeraltı kaynaklarının ehemmiyeti Arapçayı önemli kılması ve bu alanda çalışma yapmak isteyenler için Arapça öğrenmenin bir ihtiyaca dönüşmesi.

2. Ders Programı: Buradaki ders programında öğrencilere haftalık üç saat ve her bir dönem için toplamda 42 saat olmak üzere dört dönem Arapça okutmaktayız.

3. Eğitim Usûlü: Bu gruptaki öğrencilerin ihtiyacına cevap verecek ve hedeflerini gerçekleştirecek bir eğitim için dilbilgisi kurallarını tatbikî seviyede tuttuk. Bunun haricinde şu programı uyguladık.

el-Kitap’a giriş niteliğinde bölüm hocalarımız tarafından hazırlanmış çalışma kağıtlarından oluşan bir "medhal/Giriş"

Mahmut el-Batal ve diğerleri tarafından hazırlanmış el-Kitap'ın birinci cildi.

Çalışma kâğıtları ile desteklenmiş sesli ve görüntülü materyaller.

Hem el-Kitap’ın alıştırmalarını anlamaya yardımcı olacak, hem de öğrenciyi sınıf içi ve sınıf dışında zinde tutacak çalışma kâğıtları.

\section{Sonuç}

Yabancı dil öğretiminde muhatap kitlenin hedef ve ihtiyaçları göz önünde bulundurularak bir müfredat ve program hazırlanmalıdır. Bu müfredat hazırlanırken dört dil becerisinden her biri gözetilerek öğrencinin bu dil becerilerinin her birinde gelişmesini sağlamak amaç edinilmelidir. Aksi takdirde öğrenci program ve müfredatının eksik olduğunu düşünecek bu kendisinin gelişmesini etkileyecektir. Yabancı dil öğretiminde dikkat edilecek bir diğer husus ise bu müfredata uygun materyal ve yöntemlerin 
muhatap kitlenin özelliklerine göre belirlenmesidir. Muhatap kitlenin özelliklerine uygun olmayan yöntem ve materyallerle yapılacak eğitimin katkısının sınırlı olması kaçınılmazdır. Bu öğretim sürecinde öğreticiler de süreci büyük bir dikkat ve titizlikle takip etmeli ve gerek program gerek materyallerle ilgili aksaklıkları zamanında tespit etmeli ve en kısa zamanda çözümlemelidir.

\section{Kaynakça}

al-Batal, M., et-Tonsî, A., Brustad, K. (2007). el-Kitap. Washington: Georgetown University Press.

al-Battal, Mahmoud - R. Kirk Belnap“Amerika Birleşik Devletlerinde Arapça Öğretimi ve Öğrenimi: Gerçekler, İhtiyaçlar, ve Geleceğe Dair Tavsiyeler”, çeviren M. Vecih Uzunoğlu, Nüsha: Şarkiyat Araştırmaları Dergisi, 2012, sayı: 35

Başkan, Ö. (1969). Yabancı dil öğretimi : ilkeler ve çözümler. İstanbul: İstanbul Üniversitesi Edebiyat Fakültesi.

Bostancı, A. (2003). Ürdün Üniversitelerinde Yabancılara Arapça Öğretimi. Sakarya Üniversitesi İlahiyat Fakültesi Dergisi, 8, 53-97.

Bostancı, A. (2005) İlâhiyat Fakültelerinde Arapça Öğretiminde Kullanılan Ders Kitapları ve Diğer AraçGereçlerin Tespit ve Analizi. Sakarya Üniversitesi İlahiyat Fakültesi Dergisi, 11, 1-30

Civelek, Y. (1998). Türkiye'de Arapça Öğretimine Dair Bazı Teklifler -Riyad Arap Dil Enstitüsü Örneği-. Yüzüncü Yll Üniversitesi İlahiyat Fakültesi Dergisi, II, 2, 225-283

Deliçay, T. (2001). Arapça Öğretiminde Modüler Yöntem İle Geleneksel Yöntemin Karşılaştırılması (F. Ü. İlâhiyat Fakültesi Örneği). Harran Üniversitesi İlahiyat Fakültesi Dergisi, VII, 1, 89-112.

Demircan, Ö. (2013). Yabancıdil Öğretim Yöntemleri. (5. bs.). İstanbul: Der Yayınları.

Demirel, Ö. (1990). Yabancı Dil Öğretimi: İlkeler, Yöntemler, Teknikler. (2. bs.). Ankara: Usem Yayınları.

Demirel, Ö. (2003). Yabancı Dil Öğretimi; Dil Pasaportu, Dil Biyografisi, Dil Dosyası. Ankara: Pegem Yayınları.

Doğan, C. (2006). Arapça Öğretiminde Yöntem Orijinli Problemler ve Çözüm Önerileri. Nüsha: Şarkiyat Araştırmaları Dergisi, VI, 21, 69-88

Doğan, C. (2012). Sistematik Yabancı Dil Öğretim Yaklaşımı ve Yöntemleri. İstanbul: Ensar Neşriyat.

Ekmekçi, Ö. (1983). Yabancı Dil Eğitiminde Psiko-Sosyal Etmenler. Demirel, Ö. (ed.). Orta Öğretim Kurumlarında Yabancı Dil Öğretimi ve Sorunları içinde (23-26 ss.). Ankara: Türk Eğitim Derneği.

el-Huli, M. A. (1982). Esalibü't-tedrisi'l-lugati'l-Arabiyye. Riyad: Matabiü’l-Ferezdaki’t-Ticariyye.

Enginarlar, H.(1983). Yabancı Dil Öğretiminde Çeşitli Yaklaşımlar ve İşlevsel Kavramsal Yaklaşım. Demirel, Ö. (ed.). Orta Öğretim Kurumlarında Yabancı Dil Öğretimi ve Sorunları içinde (45-68 ss.). Ankara: Türk Eğitim Derneği.

Hafâcî, M. A. (2001). Arapça Öğretiminde Kâidelerle Edebî Metinler Arasındaki İrtibatın Önemi. Çev. Rahmi Yaran. Marmara Üniversitesi İlahiyat Fakültesi Dergisi, 20, 161-173.

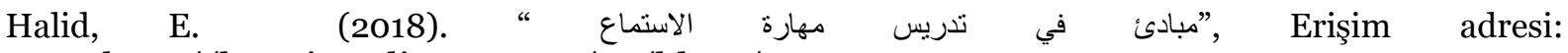

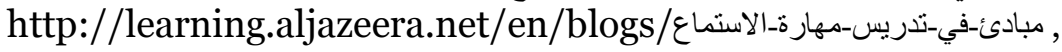

Hâtır, M. R., Şehhate, H. ve Azazi, A. (1990). el-Medhal ilâ tedrisi'l-lugati'l-Arabiyye ve't-terbiyeti'ddiniyye. Kahire:Dârü's-Sekafe.

Kaçar, H. İ. (2006). İmam-Hatip Liseleri ve İlahiyat Fakültelerinde Arapça Öğretimi Üzerine Din Ĕ̆itimi Araştırmaları Dergisi, 17, 117-133

Kocaman, A. (1983). Yabancı Dil Öğretiminde Yeni Yönelimler. Demirel, Ö. (ed.). Orta Öğretim Kurumlarında Yabancı Dil Öğretimi ve Sorunları içinde (23-26 ss.). Ankara: Türk Eğitim 
Derneği. Demirel, Ö. (ed.). Orta Öğretim Kurumlarnda Yabancı Dil Öğretimi ve Sorunları içinde (1-11 ss.). Ankara: Türk Eğitim Derneği.

Müezzin, A. D. (2016). Anadili Arapça Olmayanların Arapça Öğretiminde Başarılı Yöntem ve Stratejiler. Kahramanmaraş Sütçü İmam Üniversitesi İlahiyat Fakültesi Dergisi, XIV, 28, 97-123

Özdemir, A. (2004). İlahiyat Fakültelerinde Arapça Öğretiminin Gerekliliğ̆i, Karşılaşılan Sorunlar ve Çözüm Önerileri. Sakarya Üniversitesi İlahiyat Fakültesi Dergisi, 10, 27-50

Özgüler, Ü. (1983). Yabancı Dil Eğitiminde Araç-Gereçlerin Kullanılması. Demirel, Ö. (ed.). Orta Öğretim Kurumlarnda Yabancı Dil Öğretimi ve Sorunları içinde (134-153 ss.). Ankara: Türk Eğitim Derneği.

Şakir, M. M.(t.y.). Ta'limü'l-Lügati'l-Arabiyyeti fi Düveli'l- Komnulisi'r-Rusi. Mecelletü'lCamiati'Islamiyye, s. 373-375

Sînî, M. İ., Ebû'l-Fettah, M. H., Bedreddin, E. R., Humeyde, M. Ö. ve eş-Şa'rani A. A. (1995). el-Kiraatü'lArabiyye li’l-müslimin. Beyrut: Mektebetü Lübnan.

Soyupek, H. (2004). İlahiyat Fakültelerinde Arapça Öğretiminin Mesleki Öğretim Açısından Önemi ve Yöntem Sorunu. Süleyman Demirel Üniversitesi İlahiyat Fakültesi Dergisi, I, 12, 97-115

Suleyti, Z. S. (2002). Tedrisün-nahvi'l-Arabi fỉ dav'i'l-itticahati'l-hadise. Kahire: ed-Dârü'lMisriyyetü'l-Lübnâniyye.

Usaylî, A., (2015). el-Kavaidü'l-mühimme fi'l-lügati'l-merhaliyye limüteallimi'l-Arabiyye. Sanovber A., Yüsri, İ., el-Mansur, İ., Faris (Ed.), M. H. Ebhasu mü'temer İstanbul ed-düveli es-sani ta'limu'llugati'-Arabiyye li'n-natzkin bi-gayriha izaat ve mealim [Ebhasu Mü'temer Istanbul ed-Devli es-Sani Ta’limi'l-Lugati'l-Arabiyye li’n-Natzkin bi-Gayriha İzaat ve Mealim içinde İstanbul: İstanbul Araştırma ve Eğitim Vakfı (İSAR).

Usta, İ. (2012). Dört Temel Dil Becerisi ve Arapça Öğretimindeki Katkıları, The Four Language Skills and Their Benefits on Teaching Arabic. The Journal of Academic Social Science Studies, V, 2, 317326. 